\title{
ANALISIS FAKTOR FAKTOR YANG MEMPENGARUHI MINAT BERWIRAUSAHA (Studi Kasus Masyarakat Kelurahan Lubuk Pakam Deli Serdang)
}

\author{
${ }^{1}$ Raden Mustika Septia Devi, ${ }^{2}$ Wan Dian Safina \\ ${ }^{1,2}$ Universitas Muslim Nusantara Al-Washliyah Medan \\ ${ }^{1}$ radenmustika13@gmail.com, ${ }^{2}$ wandian.safina@gmail.com
}

\begin{abstract}
This study aims to determine the influence of internal factors, external factors and emotional factors on the interest in entrepreneurship in the Lubuk Pakam Deli Serdang Village Community. The sampling technique used the slovin sampling method, namely the sample selected by the slovin formula amounted to 90 people. Methods of data collection using a questionnaire. The results of the simultaneous hypothesis test $(F$ test) variable internal factors, external factors and emotional factors have a positive and significant effect on interest in entrepreneurship. In the partial hypothesis test ( $t$ test) the variables of internal factors, external factors and emotional factors have a positive and significant effect on interest in entrepreneurship. The results of the determination test were obtained. The coefficient of determination ( $R 2)$ was $61.6 \%$ and the remaining $38.4 \%$. This shows that the variables of internal factors, external factors and emotional factors have a positive and significant relationship with entrepreneurial interest. The results of the F test show that fcount is 6.495, while ftable is 0.207. This means that HO is rejected and Ha is accepted, because fcount > ftable, it can be interpreted that internal factors, external factors and emotional factors have a significant effect on entrepreneurial interest.
\end{abstract}

Keywords: Internal Factors, External Factors, Emotional Factors, Interests Entrepreneurship.

ABSTRAK : Penelitian ini bertujuan untuk mengetahui pengaruh Faktor internal, Faktor external dan Faktor emosional terhadap minat untuk berwirausaha di Masyarakat Kelurahan Lubuk Pakam Deli Serdang. Teknik pengambilan sampel menggunakan metode slovin sampling, yaitu sampel yang dipilih dengan rumus slovin berjumlah 90 orang. Metode pengumpulan data menggunakan kuesioner. Hasil uji hipotesis secara simultan (Uji F) variabel Faktor internal, Faktor external dan Faktor emosional berpengaruh positif dan signifikan terhadap minat berwirausaha. Pada uji hipotesis parsial (Uji t) variabel Faktor internal, Faktor external dan Faktor emosional berpengaruh positif dan signifikan terhadap minat berwirausaha. Hasil uji determinasi diperoleh Pada pengujian koefisien determinasi (R2) diperoleh 61,6\% dan sisanya 38,4\%. Hal ini menunjukan variabel Faktor internal, Faktor external dan Faktor emosional mempunyai hubungan yang positif dan signifikan terhadap Minat Berwirausaha. Hasil uji F menunjukkan fhitung sebesar 6,495, sedangkan ftabel sebesar 0.207. Artinya HO ditolak dan Ha diterima, karena fhitung > ftabel maka dapat diartikan bahwa Faktor internal, Faktor external dan Faktor emosional berpengaruh nyata terhadap Minat Berwirausaha.

Kata Kunci : Faktor Internal, Faktor Eksternal, Faktor Emosional, Minat Kewirausahaan.

\section{Pendahuluan}

Berdasarkan Fenomena di Masyarakat Kelurahan Lubuk Pakam Deli Serdang hasil wawancara yang dilakukan dengan 30 orang wirausaha pada tanggal 30-31 Maret 2021, yang kebanyakan jualan Pakaian, ada pula jualan sembako, monza (barang bekas), makanan, jualan sayuran dan lain sebagainya. Mereka berminat untuk menjadi wirausaha karna faktor peluang yang ada. Salah satunya berminat berdasarkan dari faktor eksternal misalnya bu Nila, beusia 40 tahun bertempat tinggal di Sekip. Ibu Nila sehari harinya sebagai ibu rumah tangga, akibat pandemi covid 19 dan suaminya terjadi PHK, yang mengakibatkan tidak memiliki penghasilan yang cukup untuk memenuhi kebutuhan sehari-hari. Apalagi dengan pembatasan aktivitas selama PSBB membuat sebagian besar pegawai harus bekerja di rumah 
saja, sehingga para pegawai tak jarang memesan makanan melalui online. Dari fenomena berikut inilah bu nila saat ini berminat dan termotivasi untuk berwirausaha katering makanan harian, hal ini bisa menjadi solusi bagi para pegawai yang malas keluar kantor atau rumah, maka mereka mencari makanan secara online. Selain itu kebersihan makanan pun bisa

Lebih terjamin karena menawarkan catering harian yang terjaga kebersihannya. Berdasarkan wawancara bu sari, usia 53 tahun tempat tinggal bakaran batu merupakan pedagang pakaian bekas di Masyarakat Kelurahan Lubuk Pakam Deli Serdang, maka diketahui ada pula beberapa wirausaha, berminat menjadi wirausaha karena adanya peluang untuk meraih keuntungan dengan modal yang cukup. sehingga membuat seseorang memilih jalan hidupnya menjadi entrepreneur, karena memang sudah tidak ada lagi pilihan untuknya. Fenomena yang terjadi seperti Beberapa pedagang Monza akhirnya mereka menjual barang inport yang bermerek tetapi bekas pakai atau sering disebut dengan barang loak (Monza) yang sudah di pakai dengan harga murah dan dapat menghasilkan laba yang besar, karena barang inport bekas banyak diminati oleh berbagai kalangan. Maka dari itu, mereka berminat untuk berwirausaha agar memberikan keuntungan yang besar bagi pelaku usaha yang menggelutinya.

Selain itu ada pula, bu Nanda usia 25 tahun, merupakan wirausaha online Pakaian di masyarakat Kelurahan Lubuk Pakam Deli Serdang, berminat berwirausaha dengan memanfaatkan sarana tersebut. Dengan membuat akun media sosial untuk memasarkan produk mereka. Mereka dapat mengambil gambar dan sedikit melakukan pengeditan foto produk yang kemudian dapat diunggah di akun media sosial. Maka dari itu, usaha berjualan online atau preloved dapat berdiri walaupun tanpa toko di suatu tempat.

Orang yang memiliki minat yang berbedabeda dan bekerja dalam lingkungan yang berlainan. Ada karena keinginan tercapai atau sukses maka akan memperkuat minat wirausaha. Kurangnya modal usaha yang membuat wirausaha kurang berminat untuk berwirausaha. Adanya keingin berwirausaha dan peluang untuk menentukan nasib sendiri menjadi lebih baik. Demikian juga terhadap masyarakat kelurahan Lubuk Pakam kabupaten Deli Serdang, dengan mengenal dirinya sendiri dan mengetahui minatnya, kemampuannya, dan cita-citanya.

Namun selain itu terdapat beberapa alasan yang menyebabkan mereka tidak berminat untuk memulai berwirausaha sangat sedikit, diantaranya terkendala dari modal, kemudian bingung menentukan usaha apa, takut usaha yang dijalankan tidak berhasil. niat bekerja (menjadi karyawan) yang memang sebelum menjadi lulusan.

Sebenarnya kegagalan usaha banyak disebabkan oleh mindset atau pola pikir yang keliru. Contoh pola pikir yang salah adalah anggapan bahwa "apapun yang dijual pasti akan ada yang beli." Pola pikir yang tidak benar ini juga bisa berupa menganggap sepele aspek pemasaran dan pengembangan produk yang baik sehingga cenderung sembrono dalam hal mengeluarkan uang untuk aspek-aspek bisnis yang kurang penting di awal karier dan berakibat usaha yang baru dibuka tersebut menjadi gagal. Sesuaikan bisnis Anda dengan modal yang dipunya. Jika modal terbatas, cobalah bisnis kecil-kecilan terlebih dahulu. Padahal, modal itu tidak semuanya berupa uang. Ide, keahlian, jejaring, dan keberanian untuk mengambil risiko juga menjadi modal penting dalam membangun usaha.

Berdasarkan observasi di lapangan penulis dapat menimpulkan fenomena yang terjadi di masyarakat Kelurahan Lubuk Pakam, Deli Serdang, bahwa 1) Semakin tinggi tingkat pendidikan seseorang, maka hal itu juga semakin tidak begitu berpengaruh terhadap keinginan dirinya untuk memilih jalan hidup sebagai wirausaha. Rata-rata, justru tingkat pendidikan yang tidak terlalu tinggi yang menstimulus seseorang untuk memilih kariernya menjadi seorang pengusaha. 2) Lingkungan yang sangat berpengaruh terhadap minat seseorang antara lain pergaulan dengan teman sebaya, teknologi, surat kabar dan lain-lain. Lingkungan masyarakat mempunyai peranan dan tanggung jawab yang besar di dalam rangka mewujudkan minat seseorang. 3) Lingkungan pekerjaan yang nyaman tidak akan memotivasi seorang untuk berkeinginan menjadi pengusaha. Contohnya, bila lingkungan kerja tidak nyaman, maka akan mempercepat seseorang memilih jalan kariernya untuk menjadi seorang pengusaha. 


\subsection{Rumusan Masalah}

Menurut Sugiyono (2019 : 285) "rumusan masalah merupakan suatu pertanyaan yang akan dicarikan jawabannya melalui pengumpulan data. Merumuskan masalah penelitian dapat dilakukan dalam bentuk pernyataan (problem statement) dan juga dalam bentuk pertanyaan (research question)". Adapun permasalahan yang akan diolah dalam penelitian ini, antara lain :

1) Apakah faktor dorongan dari dalam (internal) berpengaruh terhadap minatuntuk berwirausaha di Masyarakat Kelurahan Lubuk Pakam Deli Serdang?

2) Apakah faktor dorongan sosial (external) berpengaruh terhadap minat untuk berwirausaha di Masyarakat Kelurahan Lubuk Pakam Deli Serdang?

3) Apakah faktor dorongan emosional berpengaruh terhadap minat untuk berwirausaha di Masyarakat Kelurahan Lubuk Pakam Deli Serdang?

\subsection{Batasan Masalah}

Menurut Sugiyono (2019 : 281), "Karena adanya keterbatasan waktu, dana, tenaga, teoriteori, dan supaya penelitian dapat dilakukan secara lebih mendalam,

maka tidak semua masalah yang telah diidentifikasikan akan diteliti :

1) Analisis Faktor Faktor Yang Mempengaruhi Minat Berwirausaha.

2) Lokasi masyarakat Kelurahan Lubuk Pakam Deli Serdang.

\subsection{Tujuan Penelitian}

Menurut Sugiyono (2019 : 290), "Tujuan penelitian adalah untuk menemukan, mengembangkan, dan membuktikan pengetahuan dengan menggunakan prosedurprosedur ilmiah". Adapun yang menjadi tujuan penelitian ini adalah:

1) Untuk mengetahui apakah faktor dorongan dari dalam (internal) berpengaruh terhadap minat untuk berwirausaha di Masyarakat Kelurahan Lubuk Pakam Deli Serdang.

2) Untuk mengetahui apakah faktor dorongan sosial (external) berpengaruh terhadap minat untuk berwirausaha di Masyarakat Kelurahan Lubuk Pakam Deli Serdang.

3) Untuk mengetahui apakah faktor dorongan emosional berpengaruh terhadap minat untuk berwirausaha di Masyarakat Kelurahan Lubuk Pakam Deli Serdang.

\section{Metode Penelitian \\ 2.1 Populasi}

Menurut Sugiyono (2019:81) "Populasi adalah wilayah generalisasi yang terdiri atas: obyek/subyek yang mempunyai kualitas dan karakteristik tertentu yang ditetapkan oleh peneliti untuk dipelajari dan kemudian ditarik kesimpulannya". Populasi dalam penelitian ini, yang akan menjadi populasi adalah Masyarakat peserta UMKM Kelurahan Lubuk Pakam Deli Serdang sebanyak 865 orang.

\subsection{Sampel}

Menurut Sugiyono (2017:118), "Sampel adalah bagian jumlah dari karakteristik yang dimiliki oleh populasi tersebut, bila populasi besar dari peneliti tidak mungkin mempelajari semua yang ada pada populasi”. Apabila subjeknya kurang dari 100 lebih baik diambil semua hingga penelitiannya merupakan penelitian populasi, jika subjeknya lebih dari 100 dapat diambil 10\%-15\%-atau 20\%.

\subsection{Uji Normalitas}

Tujuan dari uji normalitas adalah untuk menentukan apakah variabel berdistribusi normal atau tidak. Pengujian normalitas dilakukan dengan menggunakan uji kolmogorov-smirnov test. Jika tingkat signifikansi probabilitas $>0.05$ maka data penelitian berdistribusi normal. Hasil uji normalitas dengan menggunakan program SPSS adalah sebagai berikut: 
Tabel 1. Hasil Uji Normalitas Menggunakan SPSS (Kolmogorov-Smirnov)

Dengan Variabel Dependen Minat Berwirausaha

\begin{tabular}{|c|c|c|}
\hline & & $\begin{array}{l}\text { Unstandardized } \\
\text { Residual }\end{array}$ \\
\hline $\mathrm{N}$ & & 90 \\
\hline Normal Parameters ${ }^{a}, \mathrm{~b}$ & Mean &, 0000000 \\
\hline Std. Deviation & & 2,65243170 \\
\hline Absolute Positive Negative & & ,045 \\
\hline Test Statistic & &, 045 \\
\hline Asymp. Sig. (2-tailed) & &,- 030 \\
\hline & & $\begin{array}{r}, 045 \\
200 \mathrm{c}, \mathrm{d}\end{array}$ \\
\hline & & \\
\hline
\end{tabular}

Sumber: Hasil Penelitian, 2021

Berdasarkan hasil uji normalitas di atas, terlihat nilai Asymp. Sig. (2-tailed) sebesar 0.200 dengan probabilitas $>0.05$ maka data penelitian berdistribusi normal.

\subsection{Uji Multikolinieritas}

Uji ini bertujuan untuk menguji apakah dalam model regresi ditemukan adanya korelasi antar variabel bebas. Model regresi yang baik seharusnya tidak terjadi korelasi antar variabel bebas. Untuk mendeteksi adanya multikolinieritas dapat dilakukan dengan mencari besarnya Variance Inflation Factor (VIF) dan nilai tolerancenya. Jika VIF kurang dari 10 dan nilai tolerance lebih dari 0,1 maka regresi bebas dari multikolinieritas. Hasil uji multikolinieritas dengan menggunakan software SPSS adalah sebagai berikut:

Tabel 2. Hasil Uji Multikolinieritas dengan Minat Berwirausaha sebagai Variabel Dependen

\begin{tabular}{|c|c|c|c|c|c|c|c|}
\hline \multirow[t]{2}{*}{ Model } & \multicolumn{2}{|c|}{$\begin{array}{c}\text { Unstandardized } \\
\text { Coefficients }\end{array}$} & \multirow{2}{*}{$\begin{array}{c}\begin{array}{c}\text { Standardized } \\
\text { Coefficients }\end{array} \\
\text { Beta } \\
\end{array}$} & \multirow[b]{2}{*}{$\mathrm{t}$} & \multirow[b]{2}{*}{ Sig. } & \multicolumn{2}{|c|}{$\begin{array}{c}\text { Collinearity } \\
\text { Statistics }\end{array}$} \\
\hline & $\mathrm{B}$ & Std. Error & & & & Tolerance & VIF \\
\hline 1 (Constant) & 8,023 & 3,459 & & 2,319 & ,023 & & \\
\hline Faktor internal & ,379 & ,156 & ,254 & 2,427 & ,017 & ,786 & 1,273 \\
\hline Faktor external & ,292 & ,172 & ,196 & 1,699 & ,093 & ,648 & 1,544 \\
\hline Faktor emosional &,- 123 & ,139 &,- 088 &,- 884 & ,379 & ,876 & 1,142 \\
\hline
\end{tabular}

Sumber: Hasil Penelitian, 2021

Berdasarkan Tabel 4.16 dapat diketahui bahwa nilai Variance Inflation Factor (VIF) di bawah 10 dan nilai tolerance diatas 0,1 . Jadi dapat disimpulkan tidak terjadi multikolinieritas antara variabel bebas faktor internal, faktor external, dan faktor emosional terhadap minat berwirausaha.

\subsection{Uji Heteroskedastisitas}

Hasil output SPSS uji heteroskedastisitas pada Tabel 4.19 berikut ini menunjukkan semua variabel independen memiliki tingkat signifikansi di atas 5\%, maka dapat disimpulkan model regresi tidak terdapat heteroskedastisitas. 
Tabel 3. Hasil Uji Heteroskedastisitas Minat Berwirausaha sebagai Variabel Dependen

\begin{tabular}{|c|c|c|c|c|c|}
\hline \multirow[t]{2}{*}{ Model } & \multicolumn{2}{|c|}{$\begin{array}{c}\text { Unstandardized } \\
\text { Coefficients }\end{array}$} & \multirow{2}{*}{$\begin{array}{l}\text { Standardized } \\
\text { Coefficients } \\
\text { Beta }\end{array}$} & \multirow[b]{2}{*}{$\mathrm{t}$} & \multirow[b]{2}{*}{ Sig. } \\
\hline & $\mathrm{B}$ & Std. Error & & & \\
\hline \multirow{2}{*}{$\begin{array}{l}\text { (Constant) } \\
\text { Faktor internal }\end{array}$} & $3,276 \mathrm{E}-15$ & 3,459 & &, 000 & 1,000 \\
\hline &, 000 & , 156 &, 000 &, 000 & 1,000 \\
\hline \multirow{2}{*}{$\begin{array}{l}\text { Faktor external } \\
\text { Faktor emosional }\end{array}$} & ,000 &, 172 & ,000 &, 000 & 1,000 \\
\hline &, 000 & , 139 & ,000 &, 000 & 1,000 \\
\hline
\end{tabular}

Sumber: Hasil Penelitian, 2021

Berdasarkan uji heteroskedastisitas dengan metode glejser diketahui bahwa nilai signifikan variabel Faktor internal (X1) sebesar 1,000 lebih besar dari 0,05 dan variabel Faktor external (X2) yakni 1,000 lebih besar dari 0,05 . variabel Faktor emosional (X3) yakni 1,000 lebih besar dari 0,05 . Hal ini menjelaskan bahwa tidak terjadi heterokedastistas.

\section{Hasil Dan Pembahasan}

\subsection{Analisis Regresi Berganda}

Menurut Sugiyono (2018:195), bahwa analisis regresi berganda merupakan analisis yang menghubungkan antara dua variabel independen atau lebih dengan variabel dependen. Tujuan analisis regresi berganda adalah untuk mengukur intensitas hubungan dua variabel atau lebih. Untuk menguji hipotesis digunakan pengujian statistik. Uji Regresi Linier Berganda untuk mengukur faktor faktor faktor sosial (external), dan faktor emosional mempengaruhi minat berwirausaha (studi kasus masyarakat Kelurahan Lubuk Pakam Deli Serdang..

Adapun persamaan regresi berganda tersebut menurut Sugiyono (2017:277) sebagai berikut:

$$
\mathrm{Y}=\mathrm{a}+\mathrm{b} 1 \mathrm{X} 1+\mathrm{b} 2 \mathrm{X} 2+\mathrm{e}
$$

Keterangan:

$\mathrm{Y}=$ Variabel dependen

$\mathrm{a}=$ Nilai $\mathrm{Y}$ bila $\mathrm{X}=0$ (nilai konstanta)

$\mathrm{b}=$ Koefisien regresi, yang menunjukkan angka peningkatan ataupun penurunan variabel dependen yang didasarkan pada variabel independen. Bila b (+) maka naik, dan bila (-) maka terjadi penurunan.

$\mathrm{X}=$ Variabel independen $\mathrm{e}=$ Variabel pengganggu

\subsection{Pengujian Hipotesis}

\subsubsection{Uji t (Parsial)}

Menurut Sugiyono (2017:187), bahwa uji statistik $t$ digunakan untuk pengujian hipotesis pengaruh variabel independen secara individu terhadap variabel dependen.

Untuk pengujian hipotesis tersebut digunakan statistik $t$ dengan kriteria pengambilan keputusan sebagai berikut:

a. Jika t_hitung t_tabel maka H0 ditolak dan Ha diterima pada taraf signifikan 0,05 artinya Analisis faktor faktor faktor sosial (external), dan faktor emosional ada mempengaruhi minat berwirausaha (studi kasus masyarakat Kelurahan Lubuk Pakam Deli Serdang..

b. Jika t_hitung t_tabel maka H0 diterima dan Ha ditolak pada taraf signifikan 0,05 artinya Analisis faktor faktor faktor sosial (external), dan faktor emosional tidak mempengaruhi minat berwirausaha (studi kasus masyarakat Kelurahan Lubuk Pakam Deli Serdang.

\subsubsection{Uji F (Simultan)}

Menurut Sugiyono (2017:187), bahwa uji F digunakan untuk pengujian hipotesis semua variabel independen yang dimasukkan dalam model berpengaruh secara bersama-sama terhadap variabel dependen dan juga untuk menentukan model kelayakan model regresi. Adapun kriteria pengambilan keputusan, sebagai berikut:

Jika F_hitung F_tabel pada taraf signifikan 0,05 maka $\mathrm{H} 0$ ditolak dan Ha diterima, artinya Analisis faktor faktor faktor sosial (external), dan faktor emosional mempengaruhi minat berwirausaha (studi kasus masyarakat Kelurahan Lubuk Pakam Deli Serdang. 
Jika F_hitung < F_tabel pada taraf signifikan 0,05 maka H0 diterima dan Ha ditolak, artinya secara serentak Analisis faktor faktor faktor sosial (external), dan faktor emosional tidak mempengaruhi minat berwirausaha (studi kasus masyarakat Kelurahan Lubuk Pakam Deli Serdang.

\subsection{Uji Koefisien Determinasi (r 2 )}

Menurut Kuncoro (2013:246), bahwa koefisien determinasi ( $\mathrm{r} \quad 2 \quad$ ) mengukur kemampuan model untuk menerangkan variasi variabel X1 (faktor faktor yang mempengaruhi minat berwirausaha) dan variabel X2 (masyarakat Kelurahan Lubuk Pakam Deli Serdang) terhadap variabel $\mathrm{Y}$ (Keberhasilan Usaha) atau dapat pula dikatakan sebagai pengaruh seluruh variabel independen terhadap variabel dependen.

Adapun rumus koefisien determinasi adalah:

$$
\mathrm{D}=R 2 \times 100 \%
$$

Keterangan :

$\mathrm{D}=$ Koefisien determinasi

$R 2=$ Koefisien korelasim Nilai koefisien determinasi

Menunjukkan kemampuan variabel independen dalam menjelaskan variabel dependen sangat terbatas.Jika nilai $R 2$ yang mendekati 1 (satu) berarti variabel independen memberikan hampir semua informasi yang dibutuhkan untuk memprediksi variasi variabel dependen dan model semakin tepat. Nilai angka tersebut akan diubah kebentuk persen $(\%)$, yang artinya persentase konstribusi pengaruh variabel independen terhadap dependen.

\section{Hasil Analisa}

\subsection{Pengaruh Positif Faktor Internal Terhadap Minat Berwirausaha}

Faktor internal pada dasarnya memiliki peranan tinggi dalam meningkatkan Minat Berwirausaha. Faktor internal yang tinggi harus selalu dijaga, bahkan harus ditingkatkan guna lebih baik. Wirausaha yang memiliki Faktor internal yang baik diharapkan akan mampu berusaha semaksimal mungkin untuk menyelesaikan pekerjaannya, sehingga dapat menghasilkan keuntungan yang optimal bagi dirinya sendiri. Wirausaha yang tekun berusaha dan memiliki tanggung jawab yang tinggi akan menjadi orang yang sukses.

Hasil penelitian menunjukkan bahwa variabel Faktor internal (X1) mempunyai hubungan yang positif dan signifikan terhadap Minat Berwirausaha (Y). Hasil perhitungan uji t ( uji varsial) dapat dilihat bahwa thitung > ttabel sehingga diterima dan $\mathrm{H} 0$ ditolak.

\subsection{Pengaruh Positif Faktor Eksternal Terhadap Minat Berwirausaha.}

Faktor eksternal pada dasarnya memiliki peranan dalam meningkatkan Minat Berwirausaha. Karena berawal dari kenyamanan wirausaha dalam bekerja, hubungan yang baik dengan rekan kerja, serta tersedianya fasilitas kerja maka dapat meningkatkan semangat kerja. Jika faktor eksternal yang kurang baik maka kurang baik pula minat Berwirausaha.

Hasil penelitian menunjukkan bahwa variable factor eksternal (X2) mempunyai hubungan yang positif dan sifnifikan terhadap Minat Berwirausaha (Y), hasil perhitungan uji t ( uji parsial) dapat dilihat bahwa thitung > ttabel sehingga $\mathrm{Ha}$ diterima dan $\mathrm{H} 0$ ditolak.

Hasil uji $\mathrm{F}$ menunjukkan fhitung sebesar 6,495 , sedangkan ftabel sebesar 0.207. Artinya H0 ditolak dan Ha diterima, karena fhitung > ftabel maka dapat diartikan bahwa Faktor internal, Faktor external dan Faktor emosional berpengaruh nyata terhadap Minat Berwirausaha. Pada pengujian koefisien determinasi (R2) diperoleh $61,6 \%$ dan sisanya $38,4 \%$ yang dijelaskan variabel lain. hal ini menunjukan variabel $\mathrm{X} 1, \mathrm{X} 2$ dan $\mathrm{X} 3$ mempunyai hubungan yang positif dan signifikan terhadap Y. Dari penjelasan tersebut dapat disimpulkan bahwa adanya Faktor internal, Faktor external dan Faktor emosional yang baik maka akan menghasilkan Minat Berwirausaha yang baik, sebaliknya apabila Faktor internal, Faktor external dan Faktor emosional kurang baik, akan kurang untuk Minat Berwirausaha pula. 
Tabel 4. Persentase Skor Variabel Faktor Dorongan Dari Dalam (Intenal)

\begin{tabular}{|c|l|l|l|c|l|}
\hline NO & Indikator & Skor Ideal & $\begin{array}{l}\text { Skor } \\
\text { Hasil }\end{array}$ & $\%$ & Kategori \\
\hline 1 & Hobi & 1500 & 1185 & 79 & Tinggi \\
\hline 2 & Keahlian & 1500 & 1247 & 83,13 & Tinggi \\
\hline \multirow{2}{*}{3} & $\begin{array}{l}\text { Motivasi untuk } \\
\text { kreatif }\end{array}$ & 1500 & 1260 & 84 & Tinggi \\
\hline \multicolumn{2}{|c|}{ Jumlah } & 4500 & 3692 & 82,04 & Tinggi \\
\hline
\end{tabular}

Sumber: Hasil Penelitian, 2021

Berdasarkan Tabel 4.7 menunjukkan bahwa skor ideal untuk variabel Faktor dorongan dari dalam (intenal) sebesar 4500, skor hasil perhitungan sebesar 3692 dengan persentase $82,04 \%$ termasuk dalam kategori tinggi. Sedangkan rincian untuk tiap indikator dengan skor ideal sebesar 1500 , skor hasil sebesar $1185(79 \%)$ dan

$$
\begin{aligned}
& 1247(83,13 \%) \text { dan } 1260(84 \%) \text { termasuk } \\
& \text { dalam kategori tinggi. }
\end{aligned}
$$

\section{Kesimpulan}

Berdasarkan hasil penelitian dan pembahasan dari penelitian yang telah dilakukan mengenai Analisis Faktor Faktor Yang Mempengaruhi Minat Berwirausaha (Studi Kasus Masyarakat Kelurahan Lubuk Pakam Deli Serdang, maka dapat ditarik kesimpulan sebagai berikut :

1) Faktor internal berpengaruh positif terhadap Minat Berwirausaha pada Masyarakat Kelurahan Lubuk Pakam Deli Serdang, karena persamaan regresi menunjukkan nilai positif $0,379 \mathrm{X} 1$, dapat diartikan bahwa jika faktor internal meningkat dan variabel bebas lainnya tetap, maka minat berwirausaha akan meningkat sebesar 0,379 X1

2) Faktor eksternal berpengaruh positif terhadap Minat Berwirausaha pada Masyarakat Kelurahan Lubuk Pakam Deli Serdang, karena Nilai koefisien regresi untuk variabel faktor external pada persamaan regresi menunjukkan nilaipositif 0,292 X2, dapat diartikan bahwa jika faktor external meningkat dan variabel bebas lainnya tetap, maka minat berwirausaha akan meningkat sebesar 0,292 X2.

3) Faktor emosional berpengaruh positif terhadap Minat Berwirausaha pada Masyarakat Kelurahan Lubuk Pakam Deli Serdang, karena Nilai koefisien

\section{DAFTAR PUSTAKA}

Ananda, Rusydi \& Tien Rafida, 2016. Pengantar Kewirausahaan. Medan: Perdana

Publishing

Arikunto, S. 2016. Prosedur Penelitian Suatu Pendekatan Praktik. Jakarta : Rineka

Cipta

Gogi Kurniawan (2019), Kewirausahaan Di Era Revolusi Industri 4.0 Sasanti

Institute : Banyumas.

Sugiyono. (2019). Metode Penelitian Kuantitatif kualitatif dan $R \& D$. Bandung: CV Alfabeta

Andayana, Endah. 2016. Analisis Pengalaman Belajar Kewirausahaan Terhadap Minat Berwirausaha

$$
\begin{array}{lr}
\text { Pada Program } & \text { Smk Mini } \\
\text { Pondok Pesantren. } & \text { Universitas }
\end{array}
$$

Kanjuruhan Malang.

Aptaguna, A. 2016. Pengaruh Kualitas Layanan Dan Harga Terhadap Minat Beli

Jasa Go-Jek. Program Studi Manajemen, Universitas Pembangunan Jaya.

Budiarti, Marlina. 2018. Analisis pengaruh pendidikan kewirausahaan terhadap niat kewirausahan mahasiswa (studi kasus pada mahasiswa program ekstensi fakultas ekonomi universitas Indonesia). Skripsi Sarjana Jurusan Manajemen Fakultas Ekonomi Universitas Indonesia. Salemba.

Ermawati, Novi (2016). Faktor-Faktor yang Mempengaruhi Minat Berwirausaha Mahasiswa Program studi PKK Konsentrasi Tata Busana Fakultas Teknik UNNES.

Dwi Agung Nugroho dan Sri Mulyani (2019 : 142) Pengaruh Lingkungan Internal, Lingkungan Eksternal, Respon Emosional Dan Respon Rasional Terhadap 
Perpindahan Merk (Studi pada Remaja Konsumen Sabun Mandi di Swalayan Saudara Jepara)

Irsam Darma Putra, (2018) Analisis faktor faktor yang mempengaruhi minat berwirausaha mahasiswa fakultas Ekonomi Univesitas Islam Indonesia.

Yudi Yuniarto.(2018). Minat Mahasiswa Peserta Mata Kuliah Kewirausahaan di

Jurusan Manajemen FE USD untuk berwirausaha.

Prasetyo Budi widodo (2016) Studi Korelasi Konsep Diri dan Keyakinan Diri

dengan Kewirausahaan pada Mahasiswa Prodi Psikologi FK UNDIP Semarang

Rahmadi dan Budi (2016). Analisa FaktorFaktor Yang Mempengaruhi Minat Berwirausaha Pada Mahasiswa Program Studi Manajemen Fakultas Ekonomi Universitas Kadiri, Vol.1, No. 2.

Randi Hermawansyah (2019) Minat Generasi Muda Menjadi Wirausaha komoditi kelapa (cocos Nuciferal) di kecamatan Tanjung pura kabupaten langkat provisi Sumatera Utara.

Riyan Pratama.(2019) Pengaruh Motivasi Terhadap Minat Berwirausaha Kelompok Pemuda Desa Pematang Tebih Ujungbatu.

Setyanti, dkk (2018). Pengaruh Lingkungan Keluarga dan Lingkungan Sosial Terhadap Kepribadian dan Minat Berwirausaha Mahasiswa, ISSN: 2443-

2830/2660-9471, Vol. 4, No. 1.

Yohnson.(2003). Peranan Universitas dalam Memotivasi Sarjana Menjadi Young Entrepreneurs.

Wiani, dkk (2018). Pengaruh Lingkungan Keluarga Terhadap Minat Berwirausaha Peserta Didik SMK Di Kabupaten Subang ISSN: 14126613/2527-4570, Vol.

3, No. 5, 2018.

Https://tipsserbaserbi.blogspot.com/2015/03/fa ktor-pendorong-menjadi wirausahawan. $\mathrm{Html}$

Http://lib.stikes-mw.id/wpcontent/uploads/2020/06/2.-BUKU-AJAR

Kewirausahaan .pdf (2017)

Http://repository.unpas.ac.id/41556/6/BAB\%2 0III.pdf

Https://www.bps.go.id/pressrelease/2020/05/0 5/1672/februari-2020--tingkat pengangguran -terbuka--tpt--sebesar-4-99persen.html

Https://dosenpsikologi.com/pengertian-minat- menurut-para-ahli

Http://eprints.ums.ac.id/38836/5/05.\%20BAB $\% 20$ II.pdf 